\title{
JUURNAL.RU
}

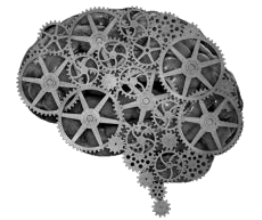

COMPANY GROUP "INTELLEKT"

Чупахин И.Н., Шкепу А.В., Герасимов С.В., Поршнев А.В., Пичхидзе С.Я. СГТУ имени Ю.А. Гагарина

Саратов, Россия

doi: 10.18411/lj2016-6-5-10

\section{Модернизация конструкции плечевого эндопротеза}

Плечевой сустав является самым подвижным суставом человека и образуется тремя костями: головкой плечевой кости, суставной или гленоидальной и ключицей. Недостатками конструкции прототипа являются: ограниченность поворота, низкий срок эксплуатации, рис.1[1].

Цель работы: усовершенствование конструкции эндопротеза в интересах увеличения времени эксплуатации. Нами предлагаются следующие изменения конструкции прототипа эндопротеза плечевого сустава: 1) модернизация ножки, 2) гидроксиапатитовое покрытие ножки [2], 3) использование титана ВТ6 (ГОСТ1987-9), 4) фторопласта-4, рис.2.

Выводы: усовершенствована конструкция эндопротеза плечевого сустава: модернизирована ножка протеза и основание гленосферы, увеличен срок его эксплуатации. Основные изменения пошли на повышение количества движения, т.к. гленосфера имеет овальную фигуру. 


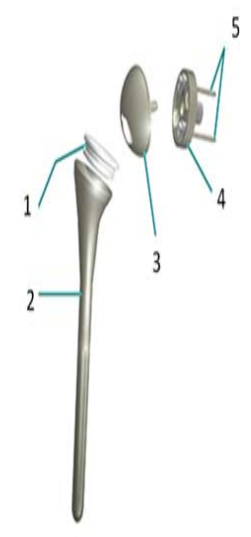

a

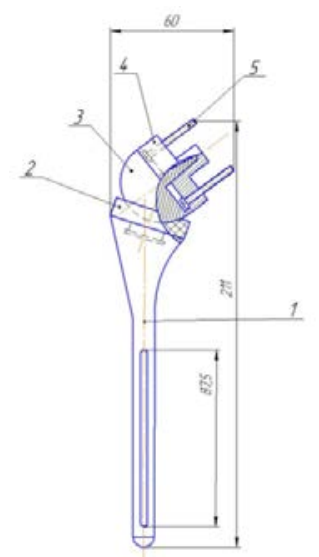

6

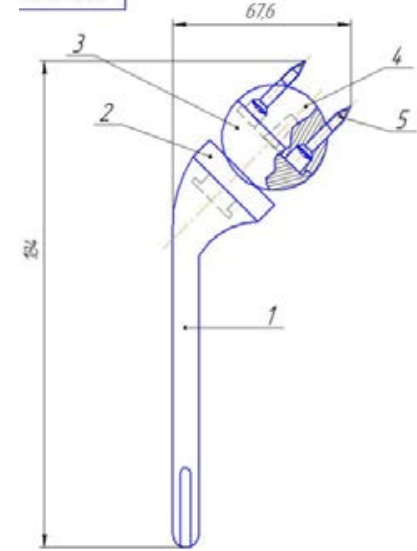

B
Рис. 1 - Схема прототипа (а) и сборочный чертеж (б), где: 1 полиэтиленовый вкладыш, 2 -ножка, 3 - головка - гленосфера, 4 основание, 5 -винты для крепления гленосферы к лопатке
Рис.2. Разработанный эндопро-тез, где: 1-ножка, 2-вкладыш из Ф-4; 3гленосфера-1, 4-глено-сфера-2, 5-винт

\section{Литература:}

1. Эндопротезы крупных суставов: каталог / Джонсон \& Джонсон, 2012.-104 c.

2. Белякова О.В., Перинская И.В., Пичхидзе С.Я. Биосовместимое антимикробное покрытие эндопротеза коленного сустава. Самара: ЛЖурнал, 2016. - 2c. 